\title{
Estimated potential for energy savings in heating residential buildings in Poland
}

\author{
Piotr Lis ${ }^{1, *}$ \\ ${ }^{1}$ Czestochowa University of Technology, Faculty of Infrastructure and Environment, \\ J.H. Dąbrowskiego 73, 42-201 Częstochowa, Poland
}

\begin{abstract}
In the face of a constant increase in demand for energy, one of the important sources will be its saving and efficient use. The search for the greatest opportunities in this area should focus on the areas where the highest energy consumption occurs. The dominant role here is played by the communal and living sector, to the extent that it is the sub-sector of buildings with a majority share of residential buildings. The article presents the expected energy effects of measures reducing energy consumption for heating residential buildings in the whole country. The author used statistical data of the Central Statistical Office available in the database of this institution. These data were identified and searched for as suitable for the purposes of this article and were used as a basis for calculations and analyses. The calculations show that only thanks to simple actions such as improvement of thermal insulation of envelope components it is possible to reduce energy consumption for heating of residential buildings by over $70 \%$ in relation to the situation in 2011 . The potential energy effect will also translate into an economic and environmental effect. Qualitative measures such as improving the performance of the heating and ventilation system of a building and/or changing the energy carrier will also reduce energy consumption for this purpose, but they are not the subject of this study. Keywords: heating of buildings, energy consumption, residential buildings, energy efficiency.
\end{abstract}

\section{Introduction}

In view of a constant increase in energy demand, it is considered that energy efficiency can become an alternative and important source of energy. The final energy consumption (FEC) in Poland increased from 57 Mtoe to 60 Mtoe between 2004 and 2014. After taking into account the climatic correction related to different meteorological conditions, the energy consumption was estimated at $63 \mathrm{Mtoe}$, and the growth rate in this period reached about $1.0 \%$ annually [1]. Although the rate of improvement in energy efficiency in Poland exceeds the European average, our economy is still characterized by high, above-average energy intensity [1].

The search for the greatest opportunities for energy savings and efficiency should focus on the areas where energy consumption is highest. The dominant role here is played by

\footnotetext{
${ }^{*}$ Corresponding author: piolis@is.pcz.czest.pl
} 
the communal and living sector, to the extent that it is the sub-sector of buildings with a majority share of residential buildings. Buildings, on average, account for approximately $41 \%[1,2]$ of total energy consumption in the European Union. Buildings built at different times, according to different existing typical construction solutions and thermal and energy requirements introduced for some time now, have different energy performances. On average, these performances differ significantly from the contemporary standards in this respect. This is the reason for the predominant share of energy consumption for space heating in the overall energy consumption of buildings and the direct reason for their relatively high operational energy intensity.

The presented data justify and strengthen the thesis that reducing energy consumption in buildings is very important for rational energy management and reducing emissions of pollutants into the air. Residential buildings (the largest functional group of buildings) play a dominant role in this process and have therefore been the subject of particular attention by the author of this publication.

\section{Aim, definitions and methods}

The aim of the presented material was to estimate the possibilities of reducing energy consumption for heating residential buildings in the whole country. The article presents the expected energy effects of measures limiting the $\mathrm{E}_{\mathrm{KH}}$ index - the final energy consumption values for heating residential buildings to the level of $55-60 \mathrm{kWh}\left(\mathrm{m}^{2}\right.$.year). The range of values determined in this way indirectly results from the fact that since 2021 Poland will be subject to a requirement concerning the maximum value of the $\mathrm{E}_{\mathrm{PH}+\mathrm{W}}$ index of the annual calculation demand of a building for non-renewable primary energy for heating and hot water production at the level of $65 \mathrm{kWh}\left(\mathrm{m}^{2}\right.$ year) for multi-family residential buildings and $70 \mathrm{kWh}\left(\mathrm{m}^{2}\right.$.year) for single-family residential buildings [3]. In the presented analyses, the baseline value for their conduct was the already mentioned $\mathrm{E}_{\mathrm{KH}}$ coefficient of final energy consumption for heating, i.e. a value that does not take into account the energy consumption for hot water production. For this reason, the range of its values obtained after reducing the $\mathrm{E}_{\mathrm{PH}+\mathrm{W}}$ index by $10 \mathrm{kWh}\left(\mathrm{m}^{2} \cdot\right.$ year $)$ has been assumed. In a simplified way, it was assumed that such a value would correspond to the energy consumption for hot water production. This roughly corresponds to about $15 \%$ of the share of energy consumption for this purpose in the total consumption for heating and heating water in a residential building.

The paper focuses mainly on relatively simple "quantitative" measures consisting in increasing the thermal insulation of envelope components and limiting heat losses from heated objects. "Qualitative" measures, such as improving the performance of the building heating and ventilation system or changing the energy carrier, have only been signaled and will be analyzed at a later stage.

The analyses were carried out using statistical data of the Central Statistical Office (GUS) available in the database of this institution in the form of thematic lists or the socalled meta data contained in individual files for supplementation purposes (listed in the literature). They were largely based on the results of the National Census carried out in 2011. It contains the most complete spectrum of data relating to various areas of Poland's economic and social life in recent years. For this reason, the reference year for the analyses carried out was 2011. Details of the statistical research methodology applied by the Central Statistical Office are described at the beginning of each source item with the data of the Central Statistical Office used by the author of the article, and additionally in [4]. The aforementioned data were searched and identified in terms of their suitability for the previously formulated purpose of the presented analysis and were the basis for the conducted estimates. However, in view of the volumes used and compared, which are 
also present in the energy performance of buildings procedure, a brief introduction containing a "definition" of these volumes is essential.

In Poland, the methodology of determining the energy performance of a building has been presented in the Regulation of the Minister of Infrastructure and Development on the methodology of determining the energy performance of a building or a part of a building and energy performance certificates [5]. The basic value used to determine the index of energy performance of residential buildings, $\mathrm{E}_{\mathrm{PH}+\mathrm{W}}$, is here the calculated value of $\mathrm{Q}_{\mathrm{p}}$ - annual non-renewable primary energy demand for technical systems in $\mathrm{kWh} /$ year. The methodology for calculating this figure includes heating, cooling and ventilation systems, hot water production, permanently installed lighting (so-called built-in lighting), which form the so-called energy use objectives to be taken into account in the methodology of energy performance of buildings. In the case of residential buildings, built-in lighting is usually not present.

In the article, the main attention is paid to heating a building. For this reason, the basic figure from which the discussion has started is $\mathrm{Q}_{\mathrm{p}, \mathrm{H}}$ - annual demand for non-renewable primary energy for the heating system. It is calculated taking into account the coefficient of non-renewable primary energy input for the production and supply of a carrier of energy or energy for heating $\mathrm{w}_{\mathrm{H}}$. The value of this coefficient largely depends on the energy policy of the state and distorts the physical dimension of the size of $\mathrm{Q}_{\mathrm{p}, \mathrm{H}}$. In Polish conditions, the values of the effort coefficient $\mathrm{w}_{\mathrm{H}}$ range from 0.0 for renewable energy sources, through 1.1-1.3 for hard coal, to 3.0 for the systemic power grid [5]. For this reason, the calculated value of $\mathrm{Q}_{\mathrm{p}, \mathrm{H}}$ cannot be compared with the calculated energy demand or the measured energy consumption for heating $\mathrm{C}_{\mathrm{H}}$. With this in mind, it has been decided that in the present case the value to be used would be that determined by the methodology of energy performance of buildings as $\mathrm{Q}_{\mathrm{k}, \mathrm{H}}$. This is the annual final energy demand delivered to a building or part of a building for the heating system in $\mathrm{kWh} /$ year which takes into account its efficiency. Similar arguments argue in favor of using a single $\mathrm{E}_{\mathrm{KH}}$ index for the annual final energy demand for building heating, which is the quotient of the annual final energy demand delivered to the building for the heating system $Q_{k, H}$ and the area of the building with controlled air temperature (heated or cooled area) $\mathrm{A}_{\mathrm{f}}$.

In addition, attention should be paid to the use of the aforementioned energy demand for the energy performance of buildings. These are calculated values and should be included in the theoretical ones. The exception is the use for energy performance of energy consumption that is the actual quantity that is obtained by direct or indirect measurement. In the case of GUS statistics on space heating, they refer to the energy consumption for this purpose (actual value) and not to the energy demand (theoretical value). The latter concept is undefined and absent from the GUS studies, e.g. [6] At the same time, however, an appropriate calculation methodology should bring the theory as close as possible to the reality of building heating. It is therefore concluded that correctly calculated values of the annual demand of $\mathrm{Q}_{\mathrm{k}, \mathrm{H}}$ and the related $\mathrm{E}_{\mathrm{KH}}$ index should be as close as possible to the value of the annual energy consumption of $\mathrm{C}_{\mathrm{H}}$ and the related unitary annual final energy consumption index for the heating of a building designated as $\mathrm{E}_{\mathrm{KCH}}$. The $\mathrm{E}_{\mathrm{KCH}}$ index is the quotient of the annual final energy consumption supplied to a building for the heating system $\mathrm{C}_{\mathrm{H}}$ and the area of the building with controlled air temperature (heated area) $\mathrm{A}_{\mathrm{f}}$.

Due to the availability of statistical data, the calculation simplifies the assumption that the area of a building or flat with controlled air temperature (heated area) $A_{f}$ is equal to the usable area $\mathrm{A}_{\mathrm{U}}$.

In view of the above, in the case of a large similarity of values, the energy demand and consumption for heating buildings can be compared, which is the case in the material presented below. 


\section{Characteristics of residential buildings}

In 2011, there were 6,047,100 buildings with at least one flat in Poland, of which 5,542,600 were residential [7]. The main focus is on the group of occupied and heated dwellings, and in principle on the dwellings located there, as they contribute to the analyzed energy consumption for space heating. There were 5,182,330 such facilities in Poland [8]. The quantitative characteristics of the buildings and apartments located there are presented in Table 1 and Table 2.

Table 1. Occupied and heated buildings and apartments constructed in Poland in various periods.

\begin{tabular}{|c|c|c|c|c|c|c|c|c|}
\hline \multirow[t]{2}{*}{$\begin{array}{c}\text { The } \\
\text { construction } \\
\text { period }\end{array}$} & \multicolumn{2}{|c|}{$\begin{array}{c}\text { Occupied } \\
\text { and heated } \\
\text { buildings [7] }\end{array}$} & \multicolumn{2}{|c|}{$\begin{array}{c}\text { Occupied } \\
\text { apartments } \\
\text { in occupied } \\
\text { and heated } \\
\text { buildings [8] }\end{array}$} & \multicolumn{2}{|c|}{$\begin{array}{c}\text { Usable area } A_{U} \\
\text { occupied apartments } \\
\text { in occupied and heated } \\
\text { buildings [9] }\end{array}$} & \multirow{2}{*}{$\begin{array}{c}\begin{array}{c}\mathbf{E} \mathbf{K}_{\mathbf{H}+\mathbf{W}} \\
{[\mathbf{1 0}]}\end{array} \\
\mathrm{kWh} / \\
\left(\mathrm{m}^{2} \cdot \text { year }\right)\end{array}$} & \multirow{2}{*}{\begin{tabular}{|c|}
$\begin{array}{c}\mathbf{E K}_{\mathrm{CH}} \\
(\text { own } \\
\text { elaboration } \\
\text { based on }[\mathbf{8} \\
\mathbf{9 , 1 1 ]})\end{array}$ \\
$\begin{array}{c}\mathrm{kWh} / \\
\left(\mathrm{m}^{2} \cdot \mathrm{year}\right)\end{array}$ \\
\end{tabular}} \\
\hline & Thous. & $\%$ & $\mathrm{mln}$ & $\%$ & Thous. $\mathrm{m}^{2}$ & $\%$ & & \\
\hline before 1918 & 404.61 & 7.81 & 1.12 & 9.25 & 68346.09 & 7.87 & $>300$ & 321.89 \\
\hline 1918-1944 & 809.22 & 15.61 & 1.39 & 11.54 & 94086.82 & 10.84 & $260-300$ & 255.08 \\
\hline $1945-1970$ & 1363.48 & 26.31 & 3.02 & 25.05 & 182847.98 & 21.06 & $220-260$ & 224.23 \\
\hline 1971-1978 & 654.03 & 12.62 & 2.03 & 16.84 & 127816.06 & 14.72 & $190-220$ & \multirow{2}{*}{197.59} \\
\hline 1979-1988 & 753.79 & 14.55 & 2.12 & 17.57 & 160657.69 & 18.51 & 140-190 & \\
\hline 1989-2002 & 670.65 & 12.94 & 1.47 & 12.16 & 134916.96 & 15.54 & $125-160$ & \multirow{3}{*}{157.90} \\
\hline 2003-2007 & 321.47 & 6.20 & 0.55 & 4.57 & 59469.97 & 6.85 & \multirow{2}{*}{$90-120$} & \\
\hline $2008-2011$ & 205.08 & 3.96 & 0.36 & 3.01 & 39942.52 & 4.60 & & \\
\hline Total & 5182.33 & 100.00 & 12.06 & 100.00 & 868084.10 & 100.00 & - & - \\
\hline
\end{tabular}

The buildings under consideration were constructed in different periods with different technical requirements for their design and construction. Of particular importance from the point of view of the energy consumption for heating buildings are the regulations concerning heat protection requirements at the beginning and, more recently, energy efficiency. The first one appeared in the Polish construction industry in the 1930s and concerned heating, indirectly only mentioning thermal insulation of building envelope without specifying the requirements in this respect. The next one was the Polish Standard PN-53/B-02405 which came into force in 1955 [2]. Subsequently, further regulations were introduced. The quality level of these requirements, however, for many years differed from their counterparts in Western European countries with similar climatic conditions to Poland[2 p.109]. It was not until 1998 that Poland began to gradually catch up in this area, with significant progress in recent years.

Buildings of different periods have different energy performance which is dominated by the energy demand for space heating, accounting for about $70 \%$ of the total energy consumption of a building. This, together with the average low thermal insulation of all buildings, is a direct cause of the relatively high energy consumption of these facilities. The energy performance of the buildings and apartments located there are presented in Table 3. 
Table 2. Occupied and heated buildings and apartments built in Poland in various periods (own elaboration based on $[8,9]$ ).

\begin{tabular}{|c|c|c|c|c|c|c|}
\hline \multirow{3}{*}{$\begin{array}{c}\text { The } \\
\text { construction } \\
\text { period }\end{array}$} & \multicolumn{2}{|c|}{$\begin{array}{c}\text { Number of occupied } \\
\text { and heated apartments }\end{array}$} & \multirow{2}{*}{$\begin{array}{c}\text { Total number } \\
\text { of occupied } \\
\text { and heated } \\
\text { apartments }\end{array}$} & \multicolumn{2}{|c|}{$\begin{array}{l}\text { Usable area } A_{U} \text { of occupied } \\
\text { and heated apartments }\end{array}$} & \multirow{2}{*}{$\begin{array}{c}\text { Total usable } \\
\text { area } A_{U} \\
\text { of occupied } \\
\text { and heated } \\
\text { apartments }\end{array}$} \\
\hline & $\begin{array}{c}\text { in single- } \\
\text { family } \\
\text { buildings }\end{array}$ & $\begin{array}{c}\text { in multi- } \\
\text { family } \\
\text { buildings }\end{array}$ & & $\begin{array}{c}\text { in single- } \\
\text { family } \\
\text { buildings }\end{array}$ & $\begin{array}{l}\text { in multi- } \\
\text { family } \\
\text { buildings. }\end{array}$ & \\
\hline & $\mathrm{mln}$ & $\mathrm{mln}$ & $\mathrm{mln}$ & $\mathrm{mln} \mathrm{m}^{2}$ & $\mathrm{mln} \mathrm{m}^{2}$ & $\mathrm{mln} \mathrm{m}^{2}$ \\
\hline before 1918 & 0.45 & 0.67 & 1.12 & 38 & 30 & 68 \\
\hline 1918-1944 & 0.56 & 0.84 & 1.39 & 52 & 42 & 94 \\
\hline $1945-1970$ & 1.20 & 1.82 & 3.02 & 102 & 81 & 183 \\
\hline 1971-1988 & 1.66 & 2.49 & 4.15 & 161 & 128 & 288 \\
\hline $1989-2011$ & 0,95 & 1.43 & 2.38 & 131 & 103 & 234 \\
\hline Total & 4.81 & 7.25 & 12.06 & 484 & 384 & 868 \\
\hline
\end{tabular}

Table 3. Energy consumption for heating of occupied and heated buildings and apartments built in Poland in various periods (own elaboration based on $[8,9,11,12]$ ).

\begin{tabular}{|c|c|c|c|c|c|c|}
\hline \multirow{3}{*}{$\begin{array}{l}\text { The } \\
\text { construction } \\
\text { period }\end{array}$} & \multicolumn{2}{|c|}{$\begin{array}{c}\text { Index of total energy } \\
\text { consumption for heating } \\
\text { (own elaboration based } \\
\text { on }[8,12])\end{array}$} & \multirow{2}{*}{$\begin{array}{c}\text { Index of total } \\
\text { energy } \\
\text { consumption } \\
\text { for heating (own } \\
\text { elaboration } \\
\text { based on [8,9, } \\
11])\end{array}$} & \multicolumn{2}{|c|}{$\begin{array}{l}\text { total energy consumption } \\
\text { for heating [12] }\end{array}$} & \multirow{2}{*}{$\begin{array}{l}\text { total energy } \\
\text { consumption } \\
\text { for heating }\end{array}$} \\
\hline & $\begin{array}{l}\text { in single- } \\
\text { family } \\
\text { buildings }\end{array}$ & $\begin{array}{l}\text { in multi- } \\
\text { family } \\
\text { buildings }\end{array}$ & & $\begin{array}{l}\text { in single- } \\
\text { family } \\
\text { buildings }\end{array}$ & $\begin{array}{l}\text { in multi- } \\
\text { family } \\
\text { buildings }\end{array}$ & \\
\hline & $\begin{array}{c}\mathrm{kWh} / \\
\left(\mathrm{m}^{2} \cdot \text { year }\right)\end{array}$ & $\begin{array}{c}\mathrm{kWh} / \\
\left(\mathrm{m}^{2} \cdot \text { year }\right)\end{array}$ & $\mathrm{kWh} /\left(\mathrm{m}^{2} \cdot\right.$ year $)$ & TWh/year & TWh/year & TWh/year \\
\hline before 1918 & 367.66 & 264.31 & 321.89 & 14 & 8 & 22 \\
\hline 1918-1944 & 306.10 & 191.31 & 255.08 & 16 & 8 & 24 \\
\hline $1945-1970$ & 265.22 & 172.74 & 224.23 & 27 & 14 & 41 \\
\hline $1971-1988$ & 230.25 & 156.52 & 197.59 & 37 & 20 & 57 \\
\hline 1989-2011 & 183.36 & 125.67 & 157.90 & 24 & 13 & 37 \\
\hline Total & $\longrightarrow$ & $\longrightarrow$ & - & 118 & 63 & 181 \\
\hline
\end{tabular}

\section{Energy efficiency of residential buildings}

The energy efficiency potential of existing buildings is very high. About $85 \%$ of residential buildings are characterized by high energy consumption, especially used for space heating, even if only the required parameters of ventilation air are maintained $[2,7]$.

An analysis of the potential for reducing energy consumption for heating residential buildings which were in operation in Poland in 2011 with a reduction of the unit value of annual energy consumption for heating to the level of $60 \mathrm{kWh} /\left(\mathrm{m}^{2}\right.$ year) for multi-family buildings and $55 \mathrm{kWh} /\left(\mathrm{m}^{2}\right.$ year $)$ for single-family buildings was carried out. Due to the energy consumption for heating in these buildings, attention was focused on occupied and heated residential buildings, of which there were 5,182,330 [7]. The usable area of the apartments located there was 868,084.1 thousand square meters [8]. A simplifying assumption has been made that the usable area is the heated area. The energy savings that can be achieved for heating if reduced to the above levels are shown in Table 4 . The calculations 
used a simplified methodology and were based on the data presented in Tables 2 and 3 concerning the total energy consumption for heating in buildings built in the analyzed time periods and usable areas of dwellings located therein. On this basis, average values of unit annual energy consumption for heating $1 \mathrm{~m}^{2}$ of apartments in particular "age" groups of buildings were calculated. The division into the periods of construction of the analyzed buildings, and thus into their "age" groups, presented in Tables 2, 3 and 4 results from the arrangement of GUS data used in the analyses by the author in a similar way.

Table 4. Reduction of specific energy consumption for heating of occupied and heated buildings and apartments built in Poland in different periods as a result of reduction of specific energy demand for heating to the level of $60 \mathrm{kWh} /\left(\mathrm{m}^{2} \cdot\right.$ year $)$ for single-family buildings, $55 \mathrm{kWh} /\left(\mathrm{m}^{2}\right.$.year) for multi-family buildings.

\begin{tabular}{|c|c|c|c|c|c|c|}
\hline \multirow{3}{*}{$\begin{array}{c}\text { The construction } \\
\text { period }\end{array}$} & \multicolumn{2}{|c|}{$\begin{array}{l}\text { Reduction of total energy } \\
\text { consumption for heating }\end{array}$} & \multirow{2}{*}{$\begin{array}{c}\text { Reduction } \\
\text { of total energy } \\
\text { consumption } \\
\text { for heating }\end{array}$} & \multicolumn{2}{|c|}{$\begin{array}{l}\text { Reduction of total energy } \\
\text { consumption for heating }\end{array}$} & \multirow{2}{*}{\begin{tabular}{|c|}
$\begin{array}{c}\text { Reduction } \\
\text { of total } \\
\text { energy } \\
\text { consumption } \\
\text { for heating }\end{array}$ \\
\end{tabular}} \\
\hline & $\begin{array}{l}\text { in single- } \\
\text { family } \\
\text { buildings }\end{array}$ & $\begin{array}{l}\text { in multi- } \\
\text { family } \\
\text { buildings }\end{array}$ & & $\begin{array}{l}\text { in single- } \\
\text { family } \\
\text { buildings }\end{array}$ & $\begin{array}{l}\text { in multi- } \\
\text { family } \\
\text { buildings }\end{array}$ & \\
\hline & TWh & TWh & TWh & $\%$ & $\%$ & $\%$ \\
\hline przed 1918 & 11.72 & 6.34 & 18.05 & 83.68 & 79.19 & 82.05 \\
\hline 1918-1944 & 12.86 & 5.70 & 18.56 & 80.40 & 71.25 & 77.35 \\
\hline $1945-1970$ & 20.89 & 9.54 & 30.43 & 77.38 & 68.16 & 74.23 \\
\hline 1971-1988 & 27.36 & 12.97 & 40.33 & 73.94 & 64.86 & 70.76 \\
\hline 1989-2011 & 16.15 & 7.31 & 23.46 & 67.28 & 56.24 & 63.40 \\
\hline Total (average) & 88.98 & 41.86 & 130.84 & (75.40) & $(66.44)$ & (72.29) \\
\hline
\end{tabular}

The differences between these calculated values of specific annual energy consumption and the previously adopted levels of reduction to $55 \mathrm{kWh} /\left(\mathrm{m}^{2} \cdot\right.$ year $)$ and $60 \mathrm{kWh} /\left(\mathrm{m}^{2} \cdot\right.$ year $)$ were the basis for estimating the energy saving potential in this respect presented in Table 5 .

Table 5. Energy saving potential for heating residential buildings.

\begin{tabular}{|c|c|c|c|c|c|}
\hline \multicolumn{4}{|c|}{ Reduction of energy consumption for heating } & \multicolumn{2}{c|}{$\begin{array}{c}\text { Reduction of total energy } \\
\text { consumption for heating }\end{array}$} \\
\cline { 1 - 3 } in single-family buildings & \multicolumn{2}{c|}{ in multi-family buildings } & & TWh & $\%$ \\
\hline TWh & $\%$ & TWh & $\%$ & 130.8 & 72.3 \\
\hline 89.0 & 75.4 & 41.9 & 66.4 & 1.4 \\
\hline
\end{tabular}

\section{Summary}

In the methodology of calculations carried out there are, of course, many simplifications which affect the accuracy of estimations. However, due to the aim of the article, they do not introduce any significant distortions to the estimated energy saving potential for heating residential buildings as a result of increasing the thermal insulation of their envelope components.

Simple calculations have estimated the savings that could be achieved by reducing the energy consumption for heating residential buildings, heated and operated in Poland in 2011 to $60 \mathrm{kWh} /\left(\mathrm{m}^{2}\right.$ year) for single-family buildings and $55 \mathrm{kWh} /\left(\mathrm{m}^{2}\right.$.year $)$ for multifamily buildings. By reducing the energy consumption for space heating to the indicated values, energy savings were obtained at an average level of $72.3 \%$ compared to the initial state. For single-family buildings these savings amounted to $75.4 \%$, and for multi-family 
buildings to $66.4 \%$. The disclosed disproportion between single and multi-family housing is caused by higher financial resources allocated in thermal modernization programs for multi-family residential buildings. The potential for annual energy savings in terms of the analyzed reduction of its consumption to heat buildings was $130.8 \mathrm{TWh} / \mathrm{year}$. Considering that in 2014 the total final energy consumption in Poland amounted to $531.4 \mathrm{TWh}$ [13], the estimated energy savings account for $24.6 \%$ of the said consumption. Such great possibilities in this area may be further increased by modernization of heating and ventilation systems in the analyzed facilities. In addition, achieving the described energy effects will be accompanied by a significant reduction in emissions of harmful substances to the atmosphere which contribute to the formation of such annoying smog in recent heating seasons. The replacement of the heat source for heating systems using coal fuels with a source using gaseous fuels will further increase the efficiency of the entire heating system, increasing the obtained energy and environmental effect. This solution is particularly important for single-family buildings and multi-family buildings built until the 1960s. Connecting existing buildings to the heat network may have a similar effect, provided that there is a reasonable technical and economic capacity (mainly in urban areas) to do so.

Reduced energy consumption for heating also means lower costs and thus an economic effect. This can significantly affect the availability of an efficient and environmentally friendly heating system. Its cost and reduced heat demand, together with significantly reduced heating costs, may be more attractive for a larger number of residents. This will help to reduce the recent phenomenon of energy poverty.

However, the achievement of the estimated results in a satisfactory scale and over time should be the subject of far-reaching state intervention.

Acknowledgements. The material was prepared as part of the statutory research of the Czestochowa University of Technology BS / PB-407-302 / 11 task 6.

\section{References}

1. Sz. Peryt, B. Asztemborski, Efektywność wykorzystania energii w latach 2004-2014. (GUS Departament Produkcji, Krajowa Agencja Poszanowania Energii S.A., Warszawa 2016)

2. P. Lis, Seria Monografie nr 263, Cechy budynków edukacyjnych a zużycie ciepła do ogrzewania, (Wydawnictwo Politechniki Częstochowskiej, Częstochowa 2013)

3. Obwieszczenie Ministra Infrastruktury i Rozwoju z dnia 17 lipca 2015 r. w sprawie ogłoszenia jednolitego tekstu rozporządzenia Ministra Infrastruktury w sprawie warunków technicznych, jakim powinny odpowiadać budynki i ich usytuowanie, (Dz.U. 2015 poz. 1422 z późniejszymi zmianami)

4. G. Kacperczyk, współpraca: H. Mikołajuk - kierownik zespołu, R. Gilecki, H. Hassman-Udrycka, J. Kacprowska, G. Parciński, M. Szymańska, Zasady metodyczne sprawozdawczości statystycznej z zakresu gospodarki paliwami i energia oraz definicje stosowanych pojęć. (GUS Departament Statystyki Gospodarczej, Warszawa 2006)

5. Rozporządzenie Ministra Infrastruktury i Rozwoju z dnia 27 lutego 2015 r. w sprawie metodologii wyznaczania charakterystyki energetycznej budynku lub części budynku oraz świadectw charakterystyki energetycznej (Dz.U. 2015 poz. 376, Warszawa 2015 z późniejszymi zmianami)

6. W. Tkaczyk, A. Kozieł, H. Mikołajuk - pod kier., GUS - Departament Produkcji, Ministerstwo Energii, Agencja Rynku Energii S.A. (ARE S.A.). Zużycie energii $w$ gospodarstwach domowych $w 2015$ r. (GUS, Warszawa 2015)

7. A. Matulska-Bachura - pod kier., K. Andrusiuk, A. Dec, E. Knyszewska, M. Przybylska, B. Różańska, M. Sobczyk, Zamieszkane budynki. Narodowy Spis Powszechny Ludności 
i Mieszkań 2011. (w tym plik: L_zamieszk_budynki_nsp_2011.xls. (Access: https://stat.gov.pl/ spisy-powszechne/nsp-2011/nsp-2011-wyniki/zamieszkane-budynkinsp-2011,15,1.html)). (GUS, Warszawa 2011)

8. A. Matulska-Bachura - pod kier., K. Andrusiuk, A. Dec, E. Knyszewska, M. Przybylska, B. Różańska, M. Sobczyk, Mieszkania. Narodowy Spis Powszechny Ludności i Mieszkań 2011. (w tym plik: PBS_nsp2011_mieszkania.xls. (Access: https://stat.gov.pl/spisy-powszechne/nsp-2011/nsp-2011-wyniki/mieszkania-narodowyspis-powszechny-ludnosci-i-mieszkan-2011,18,1.html)). (GUS, Warszawa 2011)

9. A. Matulska-Bachura - pod kier., K. Andrusiuk, E. Knyszewska, M. Przybylska, B. Różańska, M. Sobczyk, Warunki mieszkaniowe gospodarstw domowych i rodzin. Narodowy Spis Powszechny Ludności i Mieszkań 2011. (GUS Departament Handlu i Usług, Warszawa 2014)

10. S. Mańkowski, E. Szczechowiak, Zintegrowany system zmniejszenia eksploatacyjnej energochłonności budynków. Strategiczny projekt badawczy, Zadanie badawcze nr 2. Tom I, część A: Uwarunkowania przekształceń w budownictwie., (Warszawa - Poznań 2013)

11. A. Lis, P. Lis, Ograniczanie Zużycia energii do ogrzewania budynków mieszkalnych. Budownictwo o zoptymalizowanym potencjale energetycznym (to be published)

12. D. Ürge-Vorsatz, E. Wójcik-Gront, S. Tirado Herrero, E. Labzina, P. Foley, Impact on the labour market of the deep energy modernization program of buildings in Poland. (The Center for Climate Change and Sustainable Energy Policy, European Climate Foundation, Central European University, Budapest 2012)

13. Departament Produkcji GUS. Wydział Bilansów Paliw, Surowców i Materiałów. Energia. GUS, (Warszawa 2016) (https://stat.gov.pl/files/gfx/portalinformacyjny/pl/ defaultaktualnosci/5485/1/4/1/energia2016.pdf) 